\title{
The Personal Characteristics of an Islamic Counselor in Understanding Identity Crisis for Adolescents
}

\author{
Kushendar ${ }^{1}$, Hartika Utami Fitri ${ }^{2}$ \\ Universitas Negeri Semarang, Indonesia ${ }^{1}$ \\ Universitas Islam Negeri Raden Fatah Palembang, Indonesia ${ }^{2}$ \\ Q ushenefrans@gmail.com ${ }^{1}$
}

\section{Article Information: \\ Received January 9, 2018 \\ Revised January 17, 2018 \\ Accepted January 26, 2018}

\section{Keywords:}

Identity Crisis, Developmental

Crisis, Islamic Counselor as a

Person.

\begin{abstract}
Islamic counselor as a person is a reflection of self-embodied in everyday behavior which harmony with islamic sharia, and for adolescent, a role model or personal modeling is needed. And the problems that become the focus on adolescence is the identity crisis, which is one form of developmental crisis that occurs in a certain age range identity crisis also refers to the dilemma of student problems, in the form of juvenile delinquency or group behavior leading to destructive behavior. By understanding the problem a counselor is deemed able to help adolescents in overcoming the problem and also as a person is one form of reflection of Adolescence against their good person or counselor as a role model that is displayed in a personal form such as the ability to be quiet when with others, has the capacity to empathize, and other personal characteristics.
\end{abstract}

\section{INTRODUCTION}

Adolescence is one phase that will be passed by every human being in the stage of development of his life, it can be understood that adolescence is one of the most important periods in the lifespan due to the occurrence of the identity crisis. According to Hurlock (Hurlock, 2011) in the adolescent period, there is an adjustment to the group of both men and women gradually they begin to crave an identity and not satisfied with being the same with his friends with everything. In line with Erikson's opinion in the (Feist \& Feist, 2006) the search for identity ego peaked during adolescence as to find out who he really is and what his identity, with the development of puberty Adolescents, seek new roles to help them discover their sexual identity, ideological and work them. According to Erikson, there is also a crisis in Adolescents or called psychosocial crisis and adolescent problems they try to overcome is identity conflict versus identity confusion. And related to the dilemma that occurs in adolescents today phenomena that occur in adolescents or identity crises formed in the behavior commonly referred to as juvenile delinquency, such as the occurrence of brawl between schools, drug abuse, sex outside marriage, these things is a form of delinquency Adolescents who often occur today, in fact the problem is one of the transitional forms of problems faced by adolescents, in search of their identity.

Understanding the above problems can be seen that the role of parents, teachers and the environment is needed to overcome the problems they face such as how to find the identity. In addition to the role of parents, teachers and counselors also play an important role in helping the formation of identity for adolescents, counselors or counseling teachers who understand the task of development must understand the dilemmas faced by adolescents as individuals who develop.

$\begin{array}{ll}\text { How to cite : } & \text { Kushendar, K. \& Fitri, H. U. (2018). The Personal Characteristics of an Islamic Counselor in Understanding } \\ & \text { Identity Crisis for Adolescents. Is/amic Guidance and Counseling Journal, 1(1), 17-24. } \\ & \text { https://doi.org/10.25217/igcj.v1i1.187 } \\ & 2614-1566 \\ \text { E-ISSN: } & \text { Institut Agama Islam Ma'arif NU (IAIMNU) Metro Lampung } \\ \text { Published by: } & \text { https://journal.iaimnumetrolampung.ac.id/index.php/igcj } \\ \text { Available online: } & \end{array}$


One important thing to understand for a counselor is how to build good relationships for Adolescents or how to grow closeness so that counselors can easily provide a good understanding for Adolescents, understanding the task of development, recognizing the potential of yourself and also any danger that he may face, it is a linkage how counselors help shape good identity for Adolescents, a good identity is certainly a self-understanding related to the potential of Adolescents, so he can actualize themselves to the environment.

\section{DISCUSSION}

Adolescents as a growing individual that occurs in the 12-18 year age range, in the early years of adolescence are usually considered to begin when the child becomes sexually mature and ends when he reaches maturity, but more than that the task of adolescent development requires a major change in attitudes and patterns of child behavior.

Early adolescence is usually referred to as the transition from child to adulthood, the transition itself is a change of attitude and also a physical change of the child, but the transition itself according to Hurlock (Hurlock, 2011) transition does not mean interrupted with or changed from what has happened before, stage of development to the next stage. That is, what has happened before will leave its mark on what is happening now and in the future, or when children move from childhood into adulthood, children must leave everything that is childish and must also be learning patterns of behavior and attitudes that have been abandoned.

It is intended that every child's development is particularly important to the stage of adolescents, there are some things that are important to understanding the changes that occur in adolescents such as unstable emotion, One of the traits of adolescents is their unstable emotional state. They have difficulty in controlling emotions. Unable to resist desire, Adolescents usually have this trait and will ultimately impact the burden of parents because they have to fulfill the wishes of those who ask for something. In this period, some parents don't know how bad word would affect adolescents, that words like labeling could have the bad impact on the adolescent's self-concept (Kushendar \& Maba, 2017).

If not granted will cause anger and other problems arise. Easily affected. Other Adolescents are easily affected. The influence of the teenager's social environment has had an impact on the teenager. They will have a tendency to follow what is within their social circle.

Having an awkward, rigid, and shy attitude, Adolescents often have an awkward attitude, tend to be shy, and rigid when socializing in the neighborhood, not to be arranged, things to know, Adolescents have unruly nature and rebellious spirit. When you ban and even rebuke, the attitude that will be shown is rebelled frontally or just silently. But we do not misjudge, the residence of Adolescents will actually be bad, they keep all their neg or union in the heart and this will only cause a grudge in his heart.

Likes to form groups, the nature of Adolescents that we must understand next is that they like to group. It is these groups that will eventually lead to problems resulting from friction between adolescent groups. This will result in the brawl between teens and fights.

High curiosity is the age at which the child has a very strong curiosity. They are always exploring what is near them. It is near them that is feared will bring bad impact. If the thing explored is positive then the effect will be good for the child's personality later. But if the explored is negative then it will damage the personality and morale of adolescents.

Based on the above explanation can be seen that Adolescents are individuals who develop with all the problems and dilemmas faced, one of the focus of the problem is the root refers to the search identity, identity means knowing who I am, and how do I plunge into my community. The search for self-identity will involve all the things we know and learn about life and ourselves and then become one unity which is then referred to as the self-image or figure referred to by the community. 
In search of identity there is also something very important and feared in adolescents is one of the phenomena called by Erikson one of the theoreticians of personality is a denial (reduction). Erikson explains that the tendency of migration or denial is a form of the question of identity searching which in addition leads to the loss of adolescents identity, because sometimes through the wrong way Adolescents sometimes tend to let themselves "melt" in one group, especially groups that can quickly identify to them, what matters is what about the wrong group (Borooe, 2015).

Based on the results of research on the influence of adolescent conformity with the title of Emotional Maturity Relationship with Conformity in Adolescence concluded that there is a very significant positive relationship between emotional maturity with conformity in adolescents (Rachmawati, 2012). That is, the higher the emotional maturity the higher the adolescent conformity.

In the sense that this tendency is entered for groups of Adolescents or groups who are excluded from the demands of society, groups in unrest, and they may be involved with destructive activities, drugs or terrible with their group's psychotic fantasies, wrong group behavior on Adolescents would be a pretty serious problem. Here are some cases that occur in adolescents.

As quoted from detiknews.com (Masnurdiansyah, 2016) said that the brawl occurred Students from two vocational schools in Karawang regency involved brawl in Central Road Sawah, Krajan Village, District Purwasari, Karawang regency, on Wednesday afternoon today. A student named Asep Gani (17) had to die from injuries all over his body (5/10/2016).

And then the case is almost equal to the occurrence of the juvenile brawl that led to casualties that happened in Jakarta (Amelia \& Hariyanto, 2017), Police investigate the brawl between students in flyover Pasar Rebo, Ciracas, East Jakarta, the video was viral in social media. In the event that happened on February 14, one student died. "We see there is a brawl between students of SMK Adiluhur and SMK Bina Kandung. Seen there was a high school boy who did the damage, we are on the road, we take it to Kramat Jati Hospital and died on the way," said Head of Public Relations Polda Metro Jaya Kombes Argo Yuwono told reporters at Polda Metro Jaya, Jakarta, Friday (24/2/2017).

The same problem also occurred in one of the big cities of Bogor. as quoted from Berisasatu.com (Saojao, 2016), Early school entry after a long holiday colored brawl between students in Jalan Raya Bogor-Jakarta KM 48 Nangewer Sub-District, Cibinong District, Bogor Regency, Monday (28/3). Students named Herdiansyah (19) were killed after being hit by sharp objects on the head. Cibinong Police Chief, Bogor District Police, Commissioner Hida Tjohyono when confirmed tell, the brawl occurred at around 16:00 pm. At that time the two groups of students who allegedly came from the Tri Darma Vocational High School and Yapis Vocational High School met on Jalan Raya Bogor. "Perhaps among the group, there is provoked brawl, and one student named Herdiansyah was hit by the head. also collapsed and saw one student injured" said Hida, Monday (28/3/2017).

The above is certainly a dilemma for the parents of teachers and adolescents themselves, the form of juvenile delinquency such as student brawl above is a problem experienced for interpersonal Adolescents, searching identity by joining in groups that direc on brawl behavior, it becomes a focus enough to be concern for Adolescents, because sometimes their principle is better to be evil and brazen and accepted by the group than not being anyone and shunned friends. This is a concern or a form of the identity crisis in adolescents. The identity crisis is a crisis in the developing crisis.

Further, citing one of the journals put forward by Hatano explains that the problem of identity crisis is also faced by adolescents, in terms of assessing individuals or adolescents who like to consume alcohol in the country, and the result there is a positive acceptance from others compared to adolescents including non-alcoholic. While patterns may indicate that 
participants identify stronger drinkers (and social and behavioral identities) than non-alcohols (Hatano, 2016). This makes a serious dilemma in which positive acceptance is formed due to negative behavior, or in the sense of a problem occurring with remain Indonesia that negative behavior becomes one of the factors that lead to acceptance in the social environment.

The role of the counselor is crucial in helping to deal with growing teenage problems according to a research on adolescent counseling in clinics and service settings. The context of providers, as well as the context of adolescent development, is characterized and their implications for explicated contraceptive counseling (Jaccard, 2013). After reviewing the research on the effectiveness of counseling, it was concluded that there is little empirical evidence to support the effectiveness of current practice regarded as a totality. Twelve principles for effective contraceptive counseling are then derived as a basis for establishing evidence-based contraceptive protocol counseling for adolescents.

One of the services performed by counselor in dealing with free sex behavior which is a form of adolescent problem Identity crisis becomes something seriously faced by Adolescents, as in one of the research journals conducted on Iran Adolescents (Hadir, 2011) explains that the problems experienced by teenage Iran almost the same as Indonesian Adolescents one of the identity crisis. In developing countries, the decline in mental health has increased and ignored the social, family, and personal dimensions of school, such as education, personal, family, career, finance, adaptability, emotional and mental, is a problem experienced by Adolescents in Iran's adolescent problems occurs because of adolescent sensitivity mainly due to identity crises, and role confusion (gender issues).

Based on these studies can be seen that the identity crisis is a problem that many Adolescents face. Because at every stage of the development of many problems that will be faced by every individual. Developmental theories must play a part in crisis intervention. Blocher in (James, 2008) believes that the crisis movement of the stage of development through the variables of development of life is very important, the developmental crisis is one of the normal growth of man and an evolution where dramatic changes or shifts occur that produce abnormal responses. The developmental crisis is considered normal, However, all people and all unique developmental crises should be assessed and dealt with in a unique way as well. According to Erikson (Feist \& Feist, 2006) that the form of crisis does not necessarily signify a threat, but a turning point, a crucial period that will increase the fragility and dislocation of potential, the identity arises from two sources: adolescent affirmation or denial of right-child identification, young people often deny the standards of their elders, choose the values of friends of friends or friends. However, the community plays an important role in shaping their identity.

Counselor as one of the professional and social workers who served to assist and provide psychosocial services to individuals who have problems. So it can be said that the role of a counselor is a professional who provides assistance to the problematic individual where his existence is needed, especially helping learners in overcoming the identity crisis.

Counselor as a person can be interpreted as a model that is able to understand every problem of students or adolescents, understanding is the initial capital to understand what is happening to students, because a common understanding is one of the counselor personality skills according to (Gabriela, 2015) seeing the quality of counselors should also understand the skills which are owned by exploring the important qualities that a counselor should have, and to develop this skill in dealing with students. In that problem also the focus is A group and concluded that Among several aspects involved, the concept of 'diversity' implies the recognition of understanding differences individuals understand well the problem. And respect for every human being and each group can be ascertained as one of the important ways to understand the individual or adolescent differences, So counselor as a person who understands the skills of students or adolescents. 
Counselor as a person means that the outward qualities of a counselor are captivating, have the ability to be calm when with others, have the capacity to empathize, and other characteristics that have the same meaning. It can be interpreted that a counselor when with others here in a sense when facing adolescents as individuals develop counselors with sincerity and good intentions then automatically also he becomes an interesting person for others, especially at school and in adolescents, it is described as an attraction personal that can be interpreted as a good side of one's interests and pleasure towards others. In other words, when the counselor has a personal appeal would make one step to build closeness for adolescents as a growing individual.

The person of a balanced counselor can assist him in performing his duties as a calculative counselor (Marshudi, 2013). Furthermore, personality of counselor is a very important thing in counseling. A counselor must be mature, friendly, and empathetic (Gladding, 2012). They must be altruistic (concerned with the interests of others) and not easily angry or frustrated.

The personal qualities of counselors are the factors that determine the course of counseling. Not just the science and techniques that a counselor must have. The facts show (Sutoyo, 2017) that the counselee (client) does not want to go to the counselor's room to use counseling because the personality of the counselor they consider to be brave, loud, temperament, belittling students etc. Rather than, guiding the counselee to get back tho their destiny to be a believer of Allah SWT., then improve their fitrah iman (faith), jasmaniah (physically) and rohaniah (spirituality) (Sutoyo, 2013). Therefore in addition to the science of a counselor should also have a good personality, quality and adapt accountably. Personal equality between counselor and client is important in counseling activities. In overcoming the problems of adolescents, for example, the identity crisis faced by learners, for example, one of the factors causing the problem is the lack of role models or models for adolescents in shaping their personality, and a counselor who becomes self-exemplary essence or example is understood as an instrument the effectiveness.

Furthermore, the personality of an effective counselor can be seen from the foundation of self-development includes several points as follows (Awalya, 2013):

\begin{tabular}{|c|c|c|}
\hline No & $\begin{array}{l}\text { Development Platform } \\
\text { Personality }\end{array}$ & The points \\
\hline 1 & $\begin{array}{l}\text { Development of the } \\
\text { Foundation and Religious } \\
\text { Identity }\end{array}$ & $\begin{array}{l}\text { That the counselor as a helper relief is required to have an } \\
\text { understanding of religious values, } \\
\text { Strong commitment to practice these values in everyday } \\
\text { life } \\
\text { The process of assistance is worth worship and is based } \\
\text { on sincerity and patience }\end{array}$ \\
\hline 2 & Empathy Development & $\begin{array}{l}\text { Looking at the frame of reference of the counselee world } \\
\text { (internal frame of reference) } \\
\text { Putting yourself into the frame of the counselee's internal } \\
\text { perceptions } \\
\text { Feel what the counselee feels } \\
\text { Thinking with counselee, not thinking about or counselee } \\
\text { Being an emotional mirror/mirror feeling counselee } \\
\text { (emotional mirror) }\end{array}$ \\
\hline 3 & $\begin{array}{l}\text { Development of Reflection } \\
\text { on Integrity and Stability of } \\
\text { Personality }\end{array}$ & $\begin{array}{l}\text { Have a professional attitude that does not involve } \\
\text { personal problems experienced by the counselor } \\
\text { Wholeness, or integrity that comes from the quality of } \\
\text { honesty and consistency of strong character }\end{array}$ \\
\hline
\end{tabular}


Personal Development of Stress Tolerance and Frustration

Development of Counselor Positive Thinking

Development of the Counselor's personal life values

$7 \quad$ Prejudice and Cultural Stereotif

Development of Counselor's Self Management
Counselors who have a stable personality, or are able to control the negative emotions in self and the environment are

Good stress management creates measurable and achievable goals in life

Stress can be well managed menghasilkan motivasi, challenges and goals, strengths, and achievement Can anticipate and minimize the frustration of failure Think positively without seeing the negative side Positive thinking can make self-concept stronger by adding an indicator of understanding that is hope, trust, acceptance, and patience.

Have the benefits of being healthier, confident, making the right decisions, improving focus, being able to manage time, be more successful, have more friends become brave and live happier

Can make the values of life as a personal identity The value of life is a measure of attitude, words, situations, and so on

Understand the meaning of ethics, ethical etiquette of values and norms

Understanding the concept of prejudice that is feeling of tendency in action (behavioral tendency) and beliefs (beliefs)

Avoiding bad prejudices including cultural stereotypes How the counselor describes the process of achieving self-autonomy

Good control of the reaction of thoughts and feelings Understanding self-change to the counselee Able to self-directed counselee in the change of selfdirect and self-control behavior

Table 1. Development of effective counselor personality (Awalya, 2013)

\section{CONCLUSION}

Understanding teenage issues are also included in understanding the changes of selfadolescents, not only in terms of physical alone but in terms of psychic, rampant behavior or juvenile delinquency such as brawl between Adolescents, alcohol, and group behaviors that are destructive, a dilemma in today's Adolescents.

The lack of understanding and the right role model or example make Adolescents a confused person of identity or identity crisis, the form of identity crisis is one form of developmental crisis that occurs in every human, and the identity crisis becomes something that must be understood by Adolescents do not fall into deviant behavior, one of the tendencies of adolescents today is group behavior, it is considered appropriate for adolescents, since the concept of self-acceptance and recognition becomes very important for Adolescents, but entering into group behaviors will become destructive behaviors if the group itself is destructive, a counselor as a private person has a very important role important in helping the problem, one of the focussed roles is the role of counselor as a person or role model for Adolescents, a counselor who has a personal appeal to be of more value in performing his role, and an appropriate role model for Adolescents, the personal qualities are reflected in the 
attitude captivate, have the ability to be calm, have the capacity to empathize and other characteristics

\section{REFERENCE}

Amelia, M., \& Hariyanto, I. (2017). Tawuran Pelajar di Jaktim, 1 Orang Tewas. Retrieved April 26, 2017, from https://news.detik.com/berita/d-3431303/tawuran-pelajar-dijaktim-1-orang-tewas

Arikunto, S. (2006). Prosedur Penelitian, Suatu Pendekatan Praktik. Jakarta: Rineka Cipta.

Awalya, A. (2013). Pengembangan Pribadi Konselor. Yogyakarta: Deepublish.

Borooe, G. (2015). Personality theories (Melacak Kepribadian anda bersama Psikolog dunia). Yogyakarta: Prismasophie.

Feist, J., \& Feist, G. J. (2006). Theories of Personality (6th ed.). New York: McGraw Hill.

Gabriela, R. (2015). The Students' Personal and Professional Development as Psychological Counsellors. Romania: Ovidious Constanta University.

Gladding, S. T. (2012). Konseling Profesi yang Menyeluruh. Jakarta: Indeks.

Hadir, N. (2011). The Study of Counselling Services Effect on Iranian Adolescence's Mental Health. Iran: Dept. of Psychology University of Mohaghegh Ardabili.

Hatano, K. (2016). Which came first, personality traits or identity processes during early and middle adolescence? Japan: Osaka Perfecture University.

Hurlock, E. (2011). Psikologi Perkembangan, Suatu Pendekatan Sepanjang Rentang Kehidupan (5th ed.). Jakarta: Erlangga.

Jaccard, J. (2013). Counseling Adolescents About Contraception: Towards the Development of an Evidence-Based Protocol for Contraceptive Counselors. USA: New York University.

James, R. K. (2008). Crisis Intervention Strategies (6 thedition) (6th ed.). California: Brooks Cole.

Kushendar, K., \& Maba, A. P. (2017). Bahaya Label Negatif Terhadap Pembentukan Konsep Diri Anak Dengan Gangguan Belajar. Nidhomul Haq: Jurnal Manajemen Pendidikan Islam, 2(3), 95-102.

Marshudi, F. (2013). Psikologi Konseling (Buku panduan lengkap dan praktis menerapkan psikologi konseling). Yogyakarta: Divapress.

Masnurdiansyah, M. (2016). Saling Ejek, Pelajar SMK di Karawang Terlibat Tawuran Satu Orang Tewas. Retrieved April 26, 2017, from https://news.detik.com/berita/d3314413/saling-ejek-pelajar-smk-di-karawang-terlibat-tawuran-satu-orang-tewas

Rachmawati, F. (2012). Hubungan Kematangan emosi dengan konformitas pada remaja. Yogyakarta: Universitas Ahmad Dahlan.

Saojao, J. de. (2016). Tawuran Antar Pelajar di Bogor, Satu Tewas. Retrieved April 26, 2017, from http://www.beritasatu.com/megapolitan/357151-tawuran-antar-pelajar-dibogorsatu-tewas.html

Sugiyono. (2011). Statistik untuk Penelitian. Bandung: Alfabeta.

Sutoyo, A. (2013). Bimbingan dan Konseling Islam (Teori dan Praktik). Yogyakarta: Pustaka Pelajar. 
Sutoyo, A. (2017). Peran Iman dalam pengembagan pribadi konselor yang efektif. Jurnal Psikoedukasi Dan Konseling, 1(1).

Copyright Holder :

(c) Kushendar, K. \& Fitri, H. U. (2018)

First Publication Right :

(C) Islamic Guidance and Counseling Journal

This article is under :

(우(1) 